\title{
Diversidade genética entre etnovariedades de mandioca cultivadas no norte do estado de Mato Grosso por meio de descritores morfoagronômicos
}

\author{
Genetic diversity among cassava landraces cultivated in the north of Mato Grosso state, Brazil \\ using morpho-agronomic descriptors \\ Diversidad genética entre etnovariedades de yuca cultivadas en el norte del estado de Mato Grosso \\ utilizando descriptores morfoagronómicos
}

Eliane Cristina Moreno de Pedri ORCID: https://orcid.org/0000-0002-7044-581X Universidade do Estado de Mato Grosso, Brasil E-mail: elicmbio@gmail.com

Larissa Lemes dos Santos ORCID: https://orcid.org/0000-0001-7610-6694 Universidade do Estado de Mato Grosso, Brasil E-mail: larissalemes_97@outlook.com

Mariéllen Schmith Wolf ORCID: https://orcid.org/0000-0003-3056-8476 Universidade do Estado de Mato Grosso, Brasil E-mail: mariellen.wolf.5@gmail.com

Auana Vicente Tiago ORCID: https://orcid.org/0000-0001-9556-9491 Universidade do Estado de Mato Grosso, Brasil E-mail: auanavt@gmail.com

Elisa dos Santos Cardoso ORCID: https://orcid.org/0000-0001-9477-1743 Universidade do Estado de Mato Grosso, Brasil E-mail: elisabyo@gmail.com

Eulalia Soler Sobreira Hoogerheide ORCID: https://orcid.org/0000-0003-0944-3898 Embrapa Agrossilvipastoril, Brasil

E-mail: eulalia.hoogerheide@embrapa.br

Ana Aparecida Bandini Rossi ORCID: https://orcid.org/0000-0002-8318-5375 Universidade do Estado de Mato Grosso, Brasil E-mail: anabanrossi@unemat.br

\begin{abstract}
Resumo
A mandioca é uma das mais tradicionais culturas agrícolas, de relevância socioeconômica, cultivada eficientemente, em todas as regiões do Brasil. Objetivou-se neste estudo caracterizar 71 etnovariedades de mandioca, cultivadas no norte do estado de Mato Grosso, por meio de descritores morfoagronômicos, bem como destacar as etnovariedades com características desejáveis para o cultivo comercial e processamento agroindustrial. Para tanto, utilizou-se 31 descritores qualitativos e oito quantitativos. Os dados foram analisados com auxílio do software Excel e do programa Genes. Com base nos dados qualitativos evidenciou-se variabilidade fenotípica entre as etnovariedades e a formação de dez grupos genéticos pelo método UPGMA. Todas as etnovariedades apresentam raízes com mais de uma característica desejável pelos consumidores e, portanto, de interesse agronômico e comercial. Por meio dos dados quantitativos foi possível a formação de oito grupos distintos. As etnovariedades LCA09, MTA02 e MTA05 foram as mais dissimilares. Os descritores comprimento médio da raiz $(65,70 \%)$ e comprimento do pecíolo $(14,44 \%)$ foram os que mais contribuíram para a diversidade genética entre as etnovariedades. A análise conjunta dos dados reuniu as etnovariedades em nove grupos genéticos, sem duplicidade de material. Conclui-se que as etnovariedades de mandioca cultivadas por agricultores familiares no estado de Mato Grosso apresentam diversidade genética quanto aos descritores morfoagronômicos. Congregam características desejáveis pelos consumidores, apresentam potencial para cultivos comerciais e processamento agroindustrial, podendo ser úteis como progenitoras em programas de melhoramento com a espécie.ncluir o resumo.
\end{abstract}

Palavras-chave: Caracterização fenotípica; Cor da raiz; Macaxeira; Manihot esculenta Crantz; Recursos genéticos. 


\begin{abstract}
Cassava is one of the most traditional agricultural crops, it has socioeconomic relevance and it is cultivated efficiently in all regions of Brazil. The aim of this study was to characterize 71 cassava landraces, grown in the north of Mato Grosso state, Brazil, through morpho-agronomic descriptors, as well as to highlight landraces with desirable characteristics for commercial cultivation and agro-industrial processing. Thirty-one qualitative and eight quantitative descriptors were used. The data were analyzed with the aid of Excel software and the Genes program. Based on qualitative data, we observed phenotypic variability among the landraces and the formation of ten genetic groups by the UPGMA method. All landraces have roots with more than one characteristic desirable by consumers and, therefore, of agronomic and commercial interest. Through the quantitative data it was possible to form eight distinct groups. The landraces LCA09, MTA02 and MTA05 were the most dissimilar. The descriptors average length of the root $(65.70 \%)$ and length of the petiole $(14.44 \%)$ were the ones that most contributed to the genetic diversity among the landraces. The joint analysis of the data gathered the landraces into nine genetic groups, without duplication of material. We conclude that the cassava landraces cultivated by family farmers in Mato Grosso state have genetic diversity related to the morpho-agronomic descriptors. They have desirable characteristics for consumers, have the potential for commercial crops and agro-industrial processing, and can be useful as progenitors in breeding programs with the species.
\end{abstract}

Keywords: Phenotypic characterization; Root color; Macaxeira; Manihot esculenta Crantz; Genetic resources.

\title{
Resumen
}

La yuca es uno de los cultivos agrícolas más tradicionales, de relevancia socioeconómica, cultivado de manera eficiente, en todas las regiones de Brasil. El objetivo de este estudio fue caracterizar 71 etnovariedades de yuca, cultivadas en el norte del estado de Mato Grosso, mediante descriptores morfoagronómicos, así como destacar las etnovariedades con características deseables para el cultivo comercial y procesamiento agroindustrial. Para ello se utilizaron 31 descriptores cualitativos y ocho cuantitativos. Los datos se analizaron con la ayuda del software Excel y el programa Genes. Con base en datos cualitativos se evidenció variabilidad fenotípica entre etnovariedades y la formación de diez grupos genéticos por el método UPGMA. Todas las etnovariedades tienen raíces con más de una característica deseable por los consumidores y, por tanto, de interés agronómico y comercial. A través de los datos cuantitativos fue posible formar ocho grupos distintos. Las etnovariedades LCA09, MTA02 y MTA05 fueron las más disímiles. Los descriptores longitud promedio de la raíz $(65,70 \%)$ y longitud del pecíolo $(14,44 \%)$ fueron los que más contribuyeron a la diversidad genética entre las etnovariedades. El análisis conjunto de los datos reunió las etnovariedades en nueve grupos genéticos, sin duplicación de material. Se concluye que las etnovariedades de yuca cultivadas por agricultores familiares en el estado de Mato Grosso tienen diversidad genética en términos de descriptores morfoagronómicos. Reúnen características deseables por los consumidores, tienen potencial para cultivos comerciales y procesamiento agroindustrial, y pueden ser útiles como progenitores en programas de reproducción con la especie.

Palabras clave: Caracterización fenotípica; Color de la raíz; Macaxeira; Manihot esculenta Crantz; Recursos genéticos.

\section{Introdução}

O gênero Manihot Mill., pertencente à família Euphorbiaceae Juss. é endêmico dos neotropicos e tem o Brasil como o seu principal centro de origem, com cerca de $80 \%$ das espécies nativas do país. As partes vegetativas e reprodutivas dessas espécies liberam moderado odor de ácido cianídrico (HCN) que facilita o seu reconhecimento ainda no campo (BFG, 2015; Cordeiro et al., 2015). Dentre as espécies do gênero, a Manihot esculenta Crantz, popularmente conhecida como mandioca, é a única domesticada para consumo humano (Brown et al., 2013) e assume papel de destaque no mundo por ser um dos alimentos básicos mais cultivados nos trópicos (Alves; Setter, 2000).

No Brasil, a mandioca, comumente cultivada por agricultores familiares, é uma das mais tradicionais culturas agrícolas, sendo cultivada, eficientemente, nas regiões norte, nordeste, sudeste, sul e centro-oeste do país (Aplevicz; Demiate, 2007). A raiz da mandioca contém altos níveis de carboidratos, por isso é destinada a alimentação humana e animal, além de ser utilizada como matéria-prima para aplicações agroindustriais. A comercialização da mandioca é feita na forma in natura (raízes inteiras com casca), congelada (embaladas a vácuo), cozida ou pré-cozida, na forma de farinha e polvilho (Giles et al., 2018; Menezes et al., 2019). 
A mandiocultura é considerada a segunda atividade agropecuária de maior importância para a agricultura familiar matogrossense, ficando atrás apenas da pecuária de leite (Figueredo et al., 2019). Pesquisas feitas até o momento indicam elevado número de etnovariedades de mandioca cultivadas por agricultores familiares no estado de Mato Grosso apresentando diversidade genética e potencial agronômico (Oler; Amorozo, 2017; Zago et al., 2017; Pedri et al., 2019; Tiago et al., 2020). Os agricultores desempenham importante papel na conservação on farm da espécie M. esculenta, pois mantêm em suas roças distintas etnovariedades o que, além de promover a conservação das mesmas, ampliam a variabilidade genética da espécie, sendo a troca de material propagativo (manivas) um dos principais fatores que contribuem para o aumento da diversidade (Figueredo et al., 2019; Tiago et al., 2019).

A ampla variabilidade fenotípica existente dentro da espécie M. esculenta pode ser analisada por meio de estudos de diversidade genética com o emprego de descritores morfoagronômicos, qualitativos e quantitativos, de forma conjunta e complementar (Vieira et al., 2013). A caracterização por meio de descritores morfoagronômicos é fundamental para diferenciação e, posterior, conservação das etnovariedades, além de contribuir com melhoristas na identificação de genótipos superiores, possibilitando assim o desenvolvimento e a disponibilização de variedades promissoras tanto para produtores quanto para consumidores (Fuhrmann et al., 2016; Giles et al., 2018).

Os descritores morfoagronômicos têm sido amplamente utilizados na caracterização e distinção de etnovariedades de mandioca (Teixeira et al., 2014; Adjebeng-Danquah et al., 2016; Ebertz; Palomino, 2017), uma vez que os descritores morfológicos são de fácil aferição e menos influenciados pelo ambiente que os descritores agronômicos, que, por sua vez, são importantes sob o ponto de vista econômico pois contribuem para visualizar o potencial produtivo (Fukuda; Guevara, 1998), de modo que a avaliação de ambos permite distinguir as etnovariedades e identificar aquelas com maior potencial para exploração comercial.

Diante do exposto, objetivou-se neste estudo caracterizar 71 etnovariedades de mandioca, cultivadas no norte do estado de Mato Grosso, por meio de descritores morfoagronômicos, bem como destacar as etnovariedades com características desejáveis para cultivo comercial e processamento agroindustrial.

\section{Material e Métodos}

Foram coletadas manivas (material propagativo) de 71 etnovariedades de mandioca cultivadas em dez municípios situados ao longo da BR 163, no norte do estado de Mato Grosso, região Centro-Oeste do Brasil, sendo: Nova Mutum (10), Lucas do Rio Verde (10), Sorriso (10), Sinop (07), Itaúba (06), Nova Santa Helena (05), Terra Nova do Norte (04), Peixoto de Azevedo (07), Matupá (07) e Guarantã do Norte (05) (Tabela 1; Figura 1A).

Em cada município foram coletadas diferentes etnovariedades de mandioca cultivadas por agricultores familiares que diferenciam e identificam as etnovariedades presentes em suas roças a partir de características morfológicas da planta. 
Tabela 1. Etnovariedades de mandioca cultivadas em dez municípios no norte do estado de Mato Grosso, Brasil. Fonte: Autores.

\begin{tabular}{|c|c|c|c|c|c|}
\hline Código & Etnovariedades & Código & Etnovariedades & Código & Etnovariedades \\
\hline NMU01 & Camanducaia & SOR05 & Amarela 02 & TNO01 & Branca 01 \\
\hline NMU02 & Paraná & SOR06 & Branca & TNO02 & Vassourinha \\
\hline NMU03 & Cascatinha & SOR07 & Liberata & TNO03 & Cacauzinha \\
\hline NMU04 & Liberata & SOR08 & Amarela alta & TNO04 & Mandioca preta \\
\hline NMU05 & Vassourinha & SOR09 & Сасаи & PXT01 & Cacau \\
\hline NMU06 & Cacau roxa & SOR10 & Amarelinha & РXT02 & Vassourinha \\
\hline NMU07 & Mandioca sopa & SNP01 & Talo roxo & РXT03 & Branca 01 \\
\hline NMU08 & Amarelinha & SNP02 & Talo preto & PXT04 & Branca 02 \\
\hline NMU09 & Mandioca branca & SNP03 & Mandioca pão & РXT05 & Branquinha \\
\hline NMU10 & Talo avermelhado & SNP04 & Galhuda branca & РXT06 & Mandioca preta \\
\hline LCA01 & Amarela 01 & SNP05 & Talo vermelho & РXT07 & Amarelinha \\
\hline LCA02 & Amarela 02 & SNP06 & Branca & MTA01 & Vassourinha \\
\hline LCA03 & Amarela 03 & SNP07 & Amarelinha & MTA02 & Mandioca branca \\
\hline LCA04 & Amarela 04 & ITA01 & Casca roxa & MTA03 & Amarelinha \\
\hline LCA05 & Branca 01 & ITA02 & Mandioca Pão & MTA04 & Casca roxa 01 \\
\hline LCA06 & Branca 02 & ITA03 & Mandioca de 6 meses & MTA05 & Сасаи \\
\hline LCA07 & Folha roxa & ITA04 & Amarela & MTA06 & Branquinha \\
\hline LCA08 & Mandioca de fritar & ITA05 & Branca 01 & MTA07 & Casca roxa 02 \\
\hline LCA09 & Talo roxo & ITA06 & Branca 02 & GUA01 & Castelinha \\
\hline LCA10 & Mandioca de 10 meses & SHE01 & Amarelinha & GUA02 & Cacau roxa \\
\hline SOR01 & Mandioca pão & SHE02 & Mandioca roxa & GUA03 & Casca branca \\
\hline SOR02 & Mandioca de fritar & SHE03 & Branca quatro meses & GUA04 & Casca roxa \\
\hline SOR03 & Capelari & SHE04 & Cacau Branca & GUA05 & Amarelinha baixa \\
\hline SOR04 & Amarela 01 & SHE05 & Branca 01 & - & - \\
\hline
\end{tabular}

NMU = Nova Mutum; LCA = Lucas do Rio Verde; SOR = Sorriso; SNP = Sinop; ITA = Itaúba; SHE = Nova Santa Helena; TNO = Terra Nova do Norte; PXT = Peixoto de Azevedo; MTA = Matupá; GUA = Guarantã do Norte. Fonte: Autores .

Para multiplicação e, posteriores, avaliações, os materiais propagativos das etnovariedades foram plantados em novembro de 2018, início da estação chuvosa regional, na Chácara Nossa Senhora Aparecida (957’00,8”S, 5605’44,4”'W), Comunidade Central, zona rural do município de Alta Floresta, MT, Brasil (Figura 1B). O município de Alta Floresta, distante a $797 \mathrm{~km}$ da capital, Cuiabá, abrange uma área de 8.953, $213 \mathrm{~km}^{2}$ (IBGE, 2019) e apresenta clima do tipo Am, com duas estações bem definidas de seca e chuva, temperatura média entre $23{ }^{\circ} \mathrm{C}$ e $29^{\circ} \mathrm{C}$ e precipitação anual variando entre 2.500 e $3.100 \mathrm{~mm}$ (Alvares et al., 2013).

O solo da área utilizada no plantio das etnovariedades é classificado como Latossolo Vermelho-amarelo distrófico de textura argilosa de acordo com o triângulo textural (EMBRAPA, 2013). O preparo do solo foi realizado 15 dias antes do plantio e constituiu em aração e gradagem. Foram realizadas capinas manuais para o controle de plantas invasoras, representando essa o único tratamento fitossanitário aplicado.

As etnovariedades foram plantadas em linhas simples, com 15 plantas (manivas) de cada, espaçamento entre plantas e linhas de 1,0 m, bordaduras laterais, sem repetição. As manivas utilizadas no plantio mediam entre 15-20 cm de comprimento, colocadas na posição horizontal à $10 \mathrm{~cm}$ de profundidade. 
Figura 1. Localização geográfica dos municípios de coleta das etnovariedades (A) e da área experimental (B), situado na zona rural do município de Alta Floresta, Mato Grosso, Brasil.

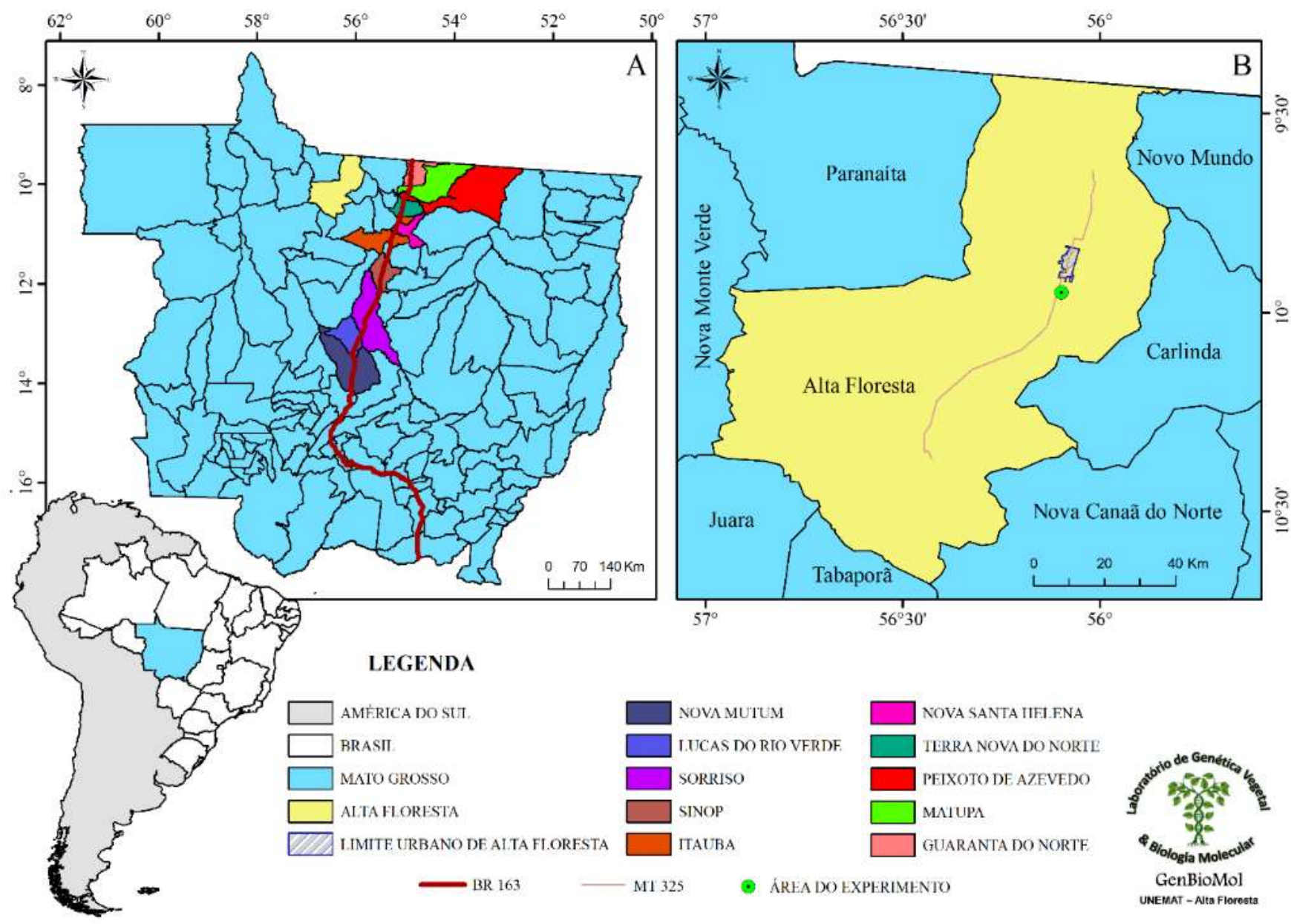

Fonte: Autores.

A caracterização fenotípica das etnovariedades foi realizada aos oito e 12 meses após o plantio, utilizando 39 descritores morfoagronômicos propostos por Fukuda e Guevara (1998), sendo 31 qualitativos (Tabela 2) e oito quantitativos. Nas avaliações foram utilizadas as cinco plantas centrais de cada etnovariedade. Os descritores qualitativos foram divididos em seis categorias: i) descritores da planta, ii) da folha apical, iii) da folha desenvolvida, iv) do pecíolo, v) do caule e vi) da raiz, conforme apresentado na Tabela 2.

Aos oito meses após o plantio foram avaliados os descritores quantitativos comprimento e largura do lóbulo central da folha desenvolvida (cm) (Figura 2A) e comprimento do pecíolo (cm). E aos 12 meses pós-plantio foram avaliadas a altura da planta (Figura 2B), altura da primeira ramificação $(\mathrm{cm})$, número de raízes por planta (contagem) (Figura 2C) e o comprimento e diâmetro médio das raízes (cm) (Figura 2D; E).

Para medição do comprimento e largura do lóbulo foliar, bem como do comprimento do pecíolo utilizou-se régua graduada. O comprimento da raiz foi determinado de uma extremidade a outra e o diâmetro foi aferido no terço médio das raízes, ambos com auxílio de uma fita métrica. A altura da planta foi mensurada utilizando régua graduada desenhada em vara de bambu, sendo efetuada a medição a partir da base da planta até seu ápice. 
Tabela 2. Categorias, descritores e classes fenotípicas utilizadas na caracterização morfoagronômica das etnovariedades de mandioca.

\begin{tabular}{|c|c|c|c|}
\hline Categorias & Descritores & Código & Classes Fenotípicas \\
\hline \multirow{3}{*}{ Planta } & Tipo da planta & TPL & \multirow{3}{*}{$\begin{array}{l}\text { 1-compacta; 2-aberta; 3-guarda-sol e 4-cilíndrica } \\
\text { 1-ereto; 2-dicotômico; 3-tricotômico e 4-tetracotômico } \\
\text { 0-nenhum ramo; 1-um nível; 2-dois níveis; 3-três níveis; 4- } \\
\text { quatro níveis e 5-cinco níveis }\end{array}$} \\
\hline & Hábito de ramificação & HRA & \\
\hline & Níveis de ramificação & NRA & \\
\hline \multirow[b]{2}{*}{ Folha apical } & \multirow{2}{*}{$\begin{array}{l}\text { Cor da folha apical } \\
\text { Pubescência do broto } \\
\text { apical }\end{array}$} & CFA & 1-verde claro; 2-verde escuro; 3 -verde arroxeado e 4-roxo \\
\hline & & PBA & 0 -ausente e 1-presente \\
\hline \multirow{5}{*}{$\begin{array}{c}\text { Folha } \\
\text { desenvolvida }\end{array}$} & $\begin{array}{l}\text { Cor da folha } \\
\text { desenvolvida }\end{array}$ & CFD & 1-verde claro; 2-verde escuro; 3 -verde arroxeado e 4-roxo \\
\hline & Cor da nervura & $\mathrm{CN}$ & $\begin{array}{l}\text { 1-verde; } 2 \text {-verde avermelhado em menos de metade; } 3 \text {-verde } \\
\text { avermelhado em mais da metade e } 4 \text {-toda vermelha }\end{array}$ \\
\hline & Forma do lóbulo & FL & $\begin{array}{l}\text { 1-ovóide; 2-elíptica-lanceolada; 3-obovada-lanceolada; 4- } \\
\text { oblongo-lanceolada; 5-lanceolada; 6-reta ou linear; 7- } \\
\text { pandurada; 8-linear-piramidal; 9-linear-pandurada e 10-linear- } \\
\text { hostatilobada }\end{array}$ \\
\hline & \multirow{2}{*}{$\begin{array}{l}\text { Número de lóbulos } \\
\text { Sinuosidade do lóbulo } \\
\text { foliar }\end{array}$} & NLO & 1-três; 2 -cinco; 3-sete; 4-nove e 5-onze \\
\hline & & SLF & 1-liso e 2-sinuoso \\
\hline \multirow{2}{*}{ Pecíolo } & Cor do pecíolo & $\mathrm{CPE}$ & $\begin{array}{l}\text { 1-verde amarelado; 2-verde; 3-verde avermelhado; 4-vermelho } \\
\text { esverdeado; 5-vermelho e 6-roxo }\end{array}$ \\
\hline & Posição do pecíolo & PPE & $\begin{array}{l}\text { 1-inclinado para cima; 2-horizontal; 3-inclinado para baixo e } \\
\text { 4-irregular }\end{array}$ \\
\hline \multirow{9}{*}{ Caule } & \multirow{3}{*}{$\begin{array}{l}\text { Cor dos ramos terminais } \\
\text { Comprimento das } \\
\text { estípulas } \\
\text { Margem das estipulas }\end{array}$} & CRT & 1- verde; 2-verde arroxeado e 3-roxo \\
\hline & & CES & 1-curtas e 2-longas \\
\hline & & MEST & 1-laciniada e 2-inteira \\
\hline & Cor externa do caule & CEXC & $\begin{array}{l}\text { 1-laranja; 2-verde amarelado; 3-dourado; 4-marrom claro; 5- } \\
\text { prateado; 6-cinza e 7-marrom escuro }\end{array}$ \\
\hline & \multirow{5}{*}{$\begin{array}{l}\text { Cor do córtex do caule } \\
\text { Cor da epiderme do } \\
\text { caule } \\
\text { Prominência das } \\
\text { cicatrizes foliares } \\
\text { Distância da filotaxia } \\
\text { Hábito de crescimento } \\
\text { do caule }\end{array}$} & $\mathrm{CCOC}$ & 1-amarelo; 2 -verde claro e 3 -verde escuro \\
\hline & & CEPC & 1-creme; 2-marrom claro; 3-marrom escuro e 4-laranja \\
\hline & & PCF & 0 -sem proeminência e 1 -proeminente \\
\hline & & DFI & 1-curto $(<8 \mathrm{~cm}) ; 2$-médio $($ de $8-15 \mathrm{~cm})$ e 3 -longo $>15 \mathrm{~cm})$ \\
\hline & & $\mathrm{HCC}$ & 1-reto e 2-zig-zag \\
\hline \multirow{10}{*}{ Raiz } & $\begin{array}{l}\text { Presença de pedúnculo } \\
\text { nas raízes }\end{array}$ & PPR & 0-séssil; 1-pedunculada e 2-mixto (ambos) \\
\hline & Posição das raízes & PR & \multirow{2}{*}{$\begin{array}{l}\text { 1-vertical; 2-horizontal e 3-irregular } \\
\text { 1-branco ou creme; 2-amarela; 3-marrom claro e 4-marrom } \\
\text { escuro }\end{array}$} \\
\hline & Cor externa da raiz & CER & \\
\hline & $\begin{array}{l}\text { Textura da epiderme da } \\
\text { raiz }\end{array}$ & TER & 1-lisa e 2-rugosa \\
\hline & Constrições da raiz & $\mathrm{CR}$ & 1-poucas ou nenhuma; 2-médias e 3-muitas \\
\hline & Forma da raiz & FR & 1-cônica; 2-cônica - cilíndrica; 3-cilíndrica e 4-irregular \\
\hline & Cor do córtex da raiz & CCR & 1-branco ou creme; 2-amarelo; 3-rosado e 4-roxo \\
\hline & \multirow{2}{*}{$\begin{array}{l}\text { Cor da polpa da raiz } \\
\text { Destaque da película da } \\
\text { raiz }\end{array}$} & CPR & 1-branca; 2-creme; 3-amarela e 4- rosada \\
\hline & & DPR & 1-fácil e 2-difícil \\
\hline & $\begin{array}{l}\text { Destaque do córtex da } \\
\text { raiz }\end{array}$ & DCR & 1-fácil e 2-difícil \\
\hline
\end{tabular}


Research, Society and Development, v. 10, n. 5, e25410514871, 2021

(CC BY 4.0) | ISSN 2525-3409 | DOI: http://dx.doi.org/10.33448/rsd-v10i5.14871

Figura 2. Ilustração de alguns descritores quantitativos utilizados na análise das 71 etnovariedades de mandioca. A) Comprimento e largura do lóbulo central da folha desenvolvida; B) Altura da planta, utilizando vara de bambu graduada; C) Contagem do número de raízes de cada planta; D e E) Comprimento e diâmetro da raiz, utilizando fita métrica.

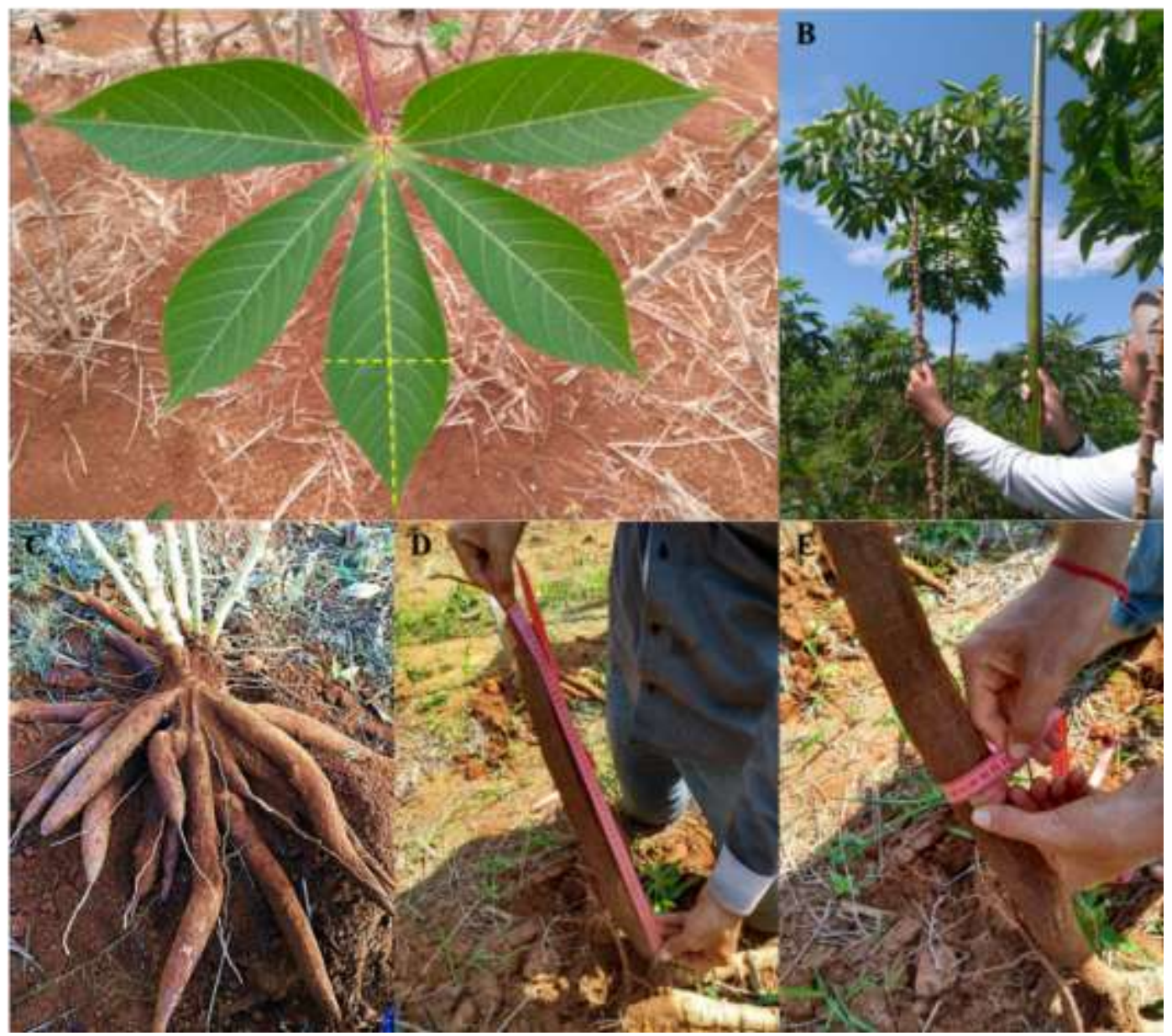

Fonte: Autores.

\subsection{Análise estatística}

\subsubsection{Distribuição de frequência das classes fenotípicas dos dados qualitativos}

Os dados qualitativos foram tabulados com auxílio do software Excel 2013 para apresentação da frequência relativa das classes fenotípicas de cada descritor, sendo está obtida por meio da fórmula 1:

$$
\text { Frequência relativa }=\frac{\text { Frequência absoluta }}{\text { Total da amostra }} \times 100
$$

\subsubsection{Caracterização qualitativa}

Os dados qualitativos foram submetidos à análise de diversidade genética como multicategóricos binários qualitativos pelo programa Genes (Cruz, 2016), onde atribui-se "0" quando uma classe está ausente no descritor e "1" quando a mesma está presente e, conforme Cruz et al. (2011), a partir dessas informações que são calculadas as medidas de dissimilaridade entre pares de acessos.

Esse índice de dissimilaridade fundamenta-se na proposta de Cole-Rodger et al. (1997) e tem a vantagem de poder ser aplicado nos casos em que os indivíduos avaliados apresentem, para uma mesma característica, mais de uma classe fenotípica. 
A matriz de dissimilaridade foi obtida, utilizando o índice correspondente à distância euclidiana média. Foi utilizado o método de agrupamento UPGMA (Unweighted pair-group method using arithmetic averages).

As cinco características qualitativas da raiz (cor da polpa como amarela; poucas ou nenhuma constrição; cor do córtex da raiz como branco ou creme; destaque do córtex como fácil e cor externa da raiz como branco ou creme), que são desejáveis sob o ponto de vista agronômico e comercial e apresentam importância para o melhoramento da espécie (Vieira et al., 2008; Tiago et al., 2020), foram agrupados pelo método UPGMA, utilizando o programa PAST v. 4.01 (Hammer et al., 2001).

\subsubsection{Caracterização quantitativa}

Para avaliação dos dados quantitativos foi utilizado o arquivo de médias convertido na distância euclidiana média. Posteriormente, utilizado o método de agrupamento UPGMA para representar a diversidade existente entre as etnovariedades. E, em seguida, foi determinado a importância relativa dos descritores conforme proposto por Singh (1981).

\subsubsection{Análise conjunta}

Uma matriz conjunta dos dados qualitativos e quantitativos foi obtida para analisar a distância genética dos indivíduos, com base no algoritmo proposto por Gower (1971), utilizando o método de agrupamento UPGMA.

Os dendrogramas foram submetidos ao ponto de corte proposto por Mojena (1977).

Todas as análises foram realizadas utilizando o programa Genes (Cruz, 2016).

\section{Resultados e Discussão}

\subsection{Distribuição de frequência das classes fenotípicas dos dados qualitativos}

Do total de descritores qualitativos (31) utilizados na caracterização das etnovariedades de mandioca, três não exibiram variação, sendo assim, todas as etnovariedades avaliadas apresentaram cicatrizes foliares proeminente, crescimento do caule reto e poucas ou nenhuma constrição nas raízes.

Os 28 descritores qualitativos apresentaram um total de 107 classes fenotípicas, destas 85\% (91) apresentaram variação, evidenciando variabilidade fenotípica entre os materiais avaliados, bem como a eficiência dos descritores qualitativos na diferenciação das etnovariedades. Conforme Vargas et al. (2018) e Vieira et al. (2008) apesar das dificuldades encontradas na avaliação desses descritores qualitativos, devido à subjetividade, essa metodologia é frequentemente utilizada em estudos de diversidade com a mandioca, pela fácil aferição, baixo custo e serem menos influenciados pelo ambiente, quando comparado ao agronômico.

Dentre os 28 descritores morfoagronômicos, seis (tipo da planta, hábito de ramificação, níveis de ramificação, comprimento das estípulas, posição das raízes e forma da raiz) apresentaram mais de uma classe fenotípica dentro da etnovariedade, ou seja, houve variação fenotípica entre as cinco plantas avaliadas de cada etnovariedade.

A frequência das classes fenotípicas das cinco categorias avaliadas (folha apical, folha desenvolvida, pecíolo, caule e raiz) estão apresentadas nas Figuras 3 e 4. Os descritores forma do lóbulo (FL) e cor do pecíolo (CPE) foram os que mais apresentaram variação, considerando que as etnovariedades avaliadas se distribuíram entre cinco e seis classes fenotípicas, respectivamente. Já a cor do córtex e da epiderme do caule (CCOC e CEPC) foram os que menos divergiram entre as etnovariedades, sendo que 59\% apresentaram córtex verde escuro e 51\% epiderme de coloração marrom claro. 
Figura 2. Frequência relativa (\%) das classes fenotípicas dos descritores qualitativos da folha apical, folha desenvolvida e pecíolo. $\mathrm{CFA}=$ Cor da folha apical; PBA = Pubescência do broto apical; FL = Forma do lóbulo; CFD = Cor da folha desenvolvida; $\mathrm{NLO}=$ Número de lóbulos; $\mathrm{CN}=$ Cor da nervura; $\mathrm{SLF}=$ Sinuosidade do lóbulo foliar; CPE = Cor do pecíolo; PPE $=$ Posição do pecíolo.

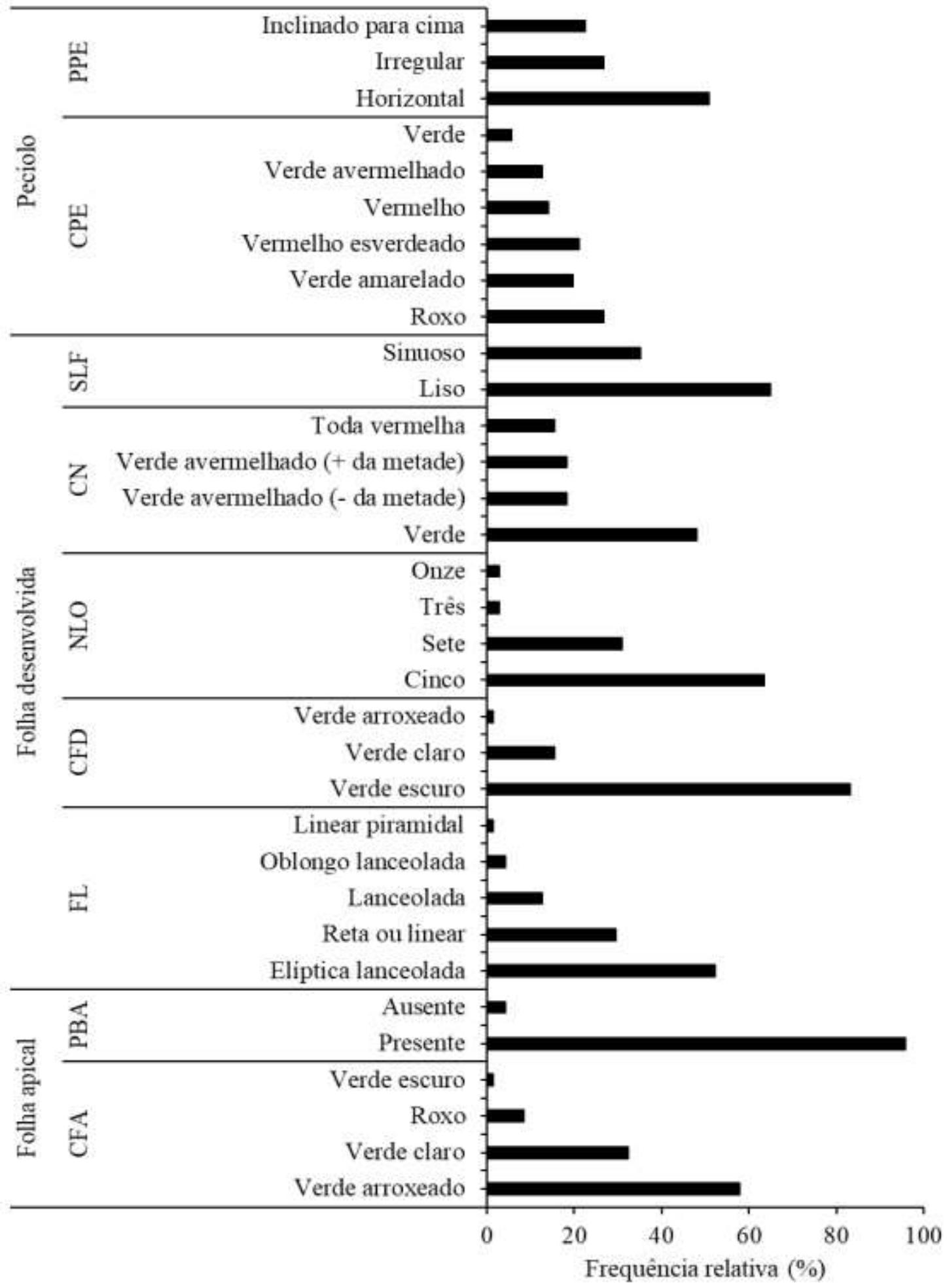

Fonte: Autores. 
Figura 3. Frequência relativa (\%) das classes fenotípicas dos descritores qualitativos do caule e da raiz. CRT $=$ Cor dos ramos terminais; MEST = Margem das estípulas $;$ CEXC = Cor externa do caule $;$ CCOC = Cor do córtex do caule CEPC $=$ Cor da epiderme do caule; DFI = Distância da filotaxia; $P P R=$ Presença de pedúnculo nas raízes; TER = Textura da epiderme da raiz; $\mathrm{CER}=$ Cor externa da raiz; CCR = Cor do córtex da raiz; CPR = Cor da polpa da raiz; DPR = Destaque da película da raiz; $\mathrm{DCR}=$ Destaque do córtex da raiz.

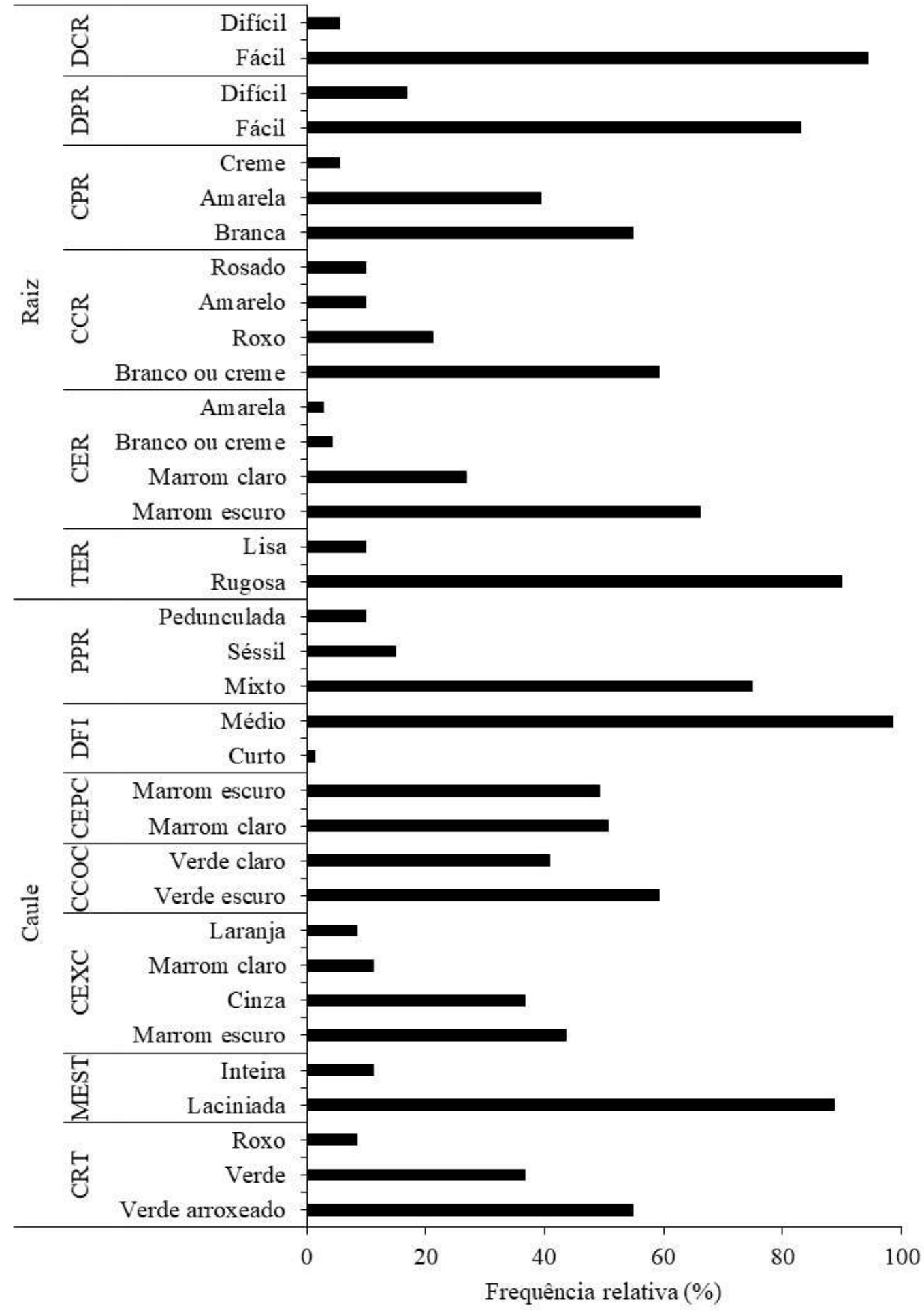

Fonte: Autores. 


\subsection{Caracterização qualitativa}

Com base nos dados qualitativos, as 71 etnovariedades de mandioca se agruparam, pelo método UPGMA, em dez grupos distintos (Figura 5). O grupo I é o mais representativo (31\%), compreendendo etnovariedades de nove municípios de abrangência do estudo e apresentando ampla variabilidade para os descritores avaliados. As características que mais contribuíram para a separação das etnovariedades deste grupo foram o comprimento médio da filotaxia, cor externa da raiz marrom escuro, epiderme da raiz rugosa e destaque fácil do córtex da raiz. Neste grupo também foi possível verificar as etnovariedades com menor distância genética (SHE05 e ITA05 = 0,164), sendo estas coletadas nos municípios de Nova Santa Helena e Itaúba.

Figura 4. Dendrograma obtido pelo método de agrupamento UPGMA de 71 etnovariedades de mandioca com base em 31 descritores morfoagronômicos qualitativos. Coeficiente de correlação cofenética $(\mathrm{CCC})=0,71$; Ponto de corte $=83,92 \%$.

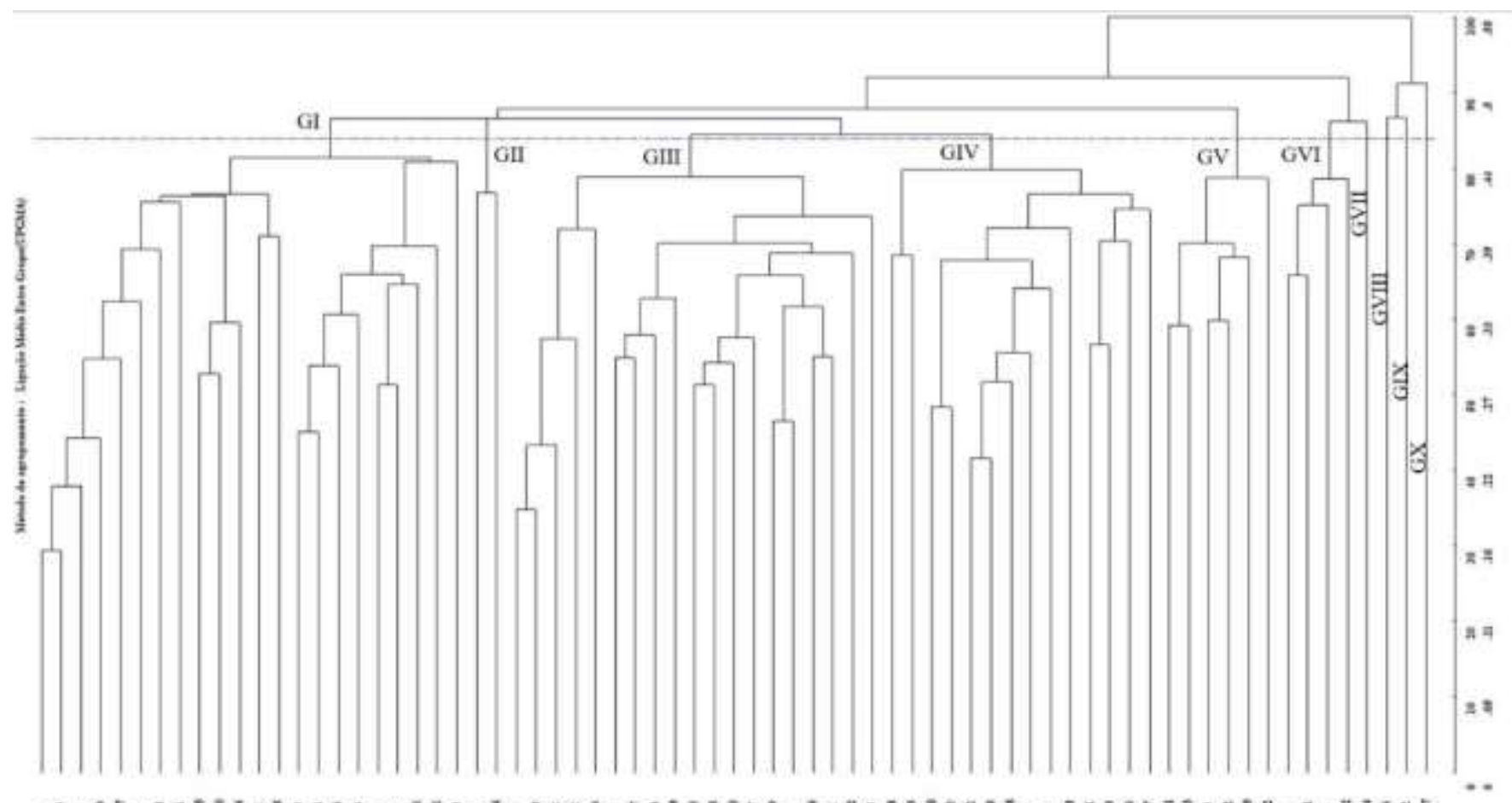

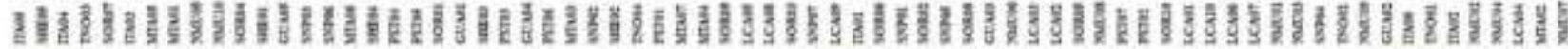

Fonte: Autores.

O grupo II foi composto por duas etnovariedades (PXT03 e GUA04, respectivamente), enquanto o grupo III alocou $27 \%$ das mandiocas avaliadas que se diferenciam das demais por apresentarem caule com córtex verde escuro, filotaxia média, epiderme da raiz rugosa, estípulas laciniadas e lóbulo foliar liso. O grupo IV, constituiu-se por $20 \%$ das etnovariedades avaliadas que apresentam folha apical verde arroxeada, broto apical pubescente, ramos terminais verde arroxeado, película da raiz com destaque fácil e córtex da raiz com destaque fácil, foram determinantes para separá-las do grupo anterior. $\mathrm{O}$ grupo $\mathrm{V}$ e VI reuniram seis e quatro etnovariedades, respectivamente, que apresentaram padrão fenotípico semelhante.

As etnovariedades Liberata (NMU04), Amarela 04 (LCA04), Mandioca branca (MTA02) e Mandioca sopa (NMU07) mostraram-se bastante divergentes das demais, formando grupos exclusivos (GVII, GVIII, GIX e GX, respectivamente). Vale ressaltar que os grupos VIII, IX e X tem origem comum no dendrograma, ou seja, faziam parte do mesmo grupo, porém, com o ponto de corte a $83,92 \%$ formou-se três grupos exclusivos, separando assim essas etnovariedades 
e a cor externa da raiz foi o descritor que contribuiu para a separação das mesmas, apresentando-se como marrom claro, marrom escuro e branco ou creme, respectivamente.

Conforme Figura 6, representada pelo agrupamento UPGMA, houve a formação de dois grandes grupos entre as etnovariedades, com base nas características de raízes com interesse para comercialização. Todas as etnovariedades apresentam raízes com mais de uma característica desejável pelos consumidores e, portanto, de interesse agronômico e comercial.

Figura 5. Dendrograma obtido pelo método de agrupamento UPGMA a partir de cinco características qualitativas da raiz para as 71 etnovariedades de mandioca avaliadas.

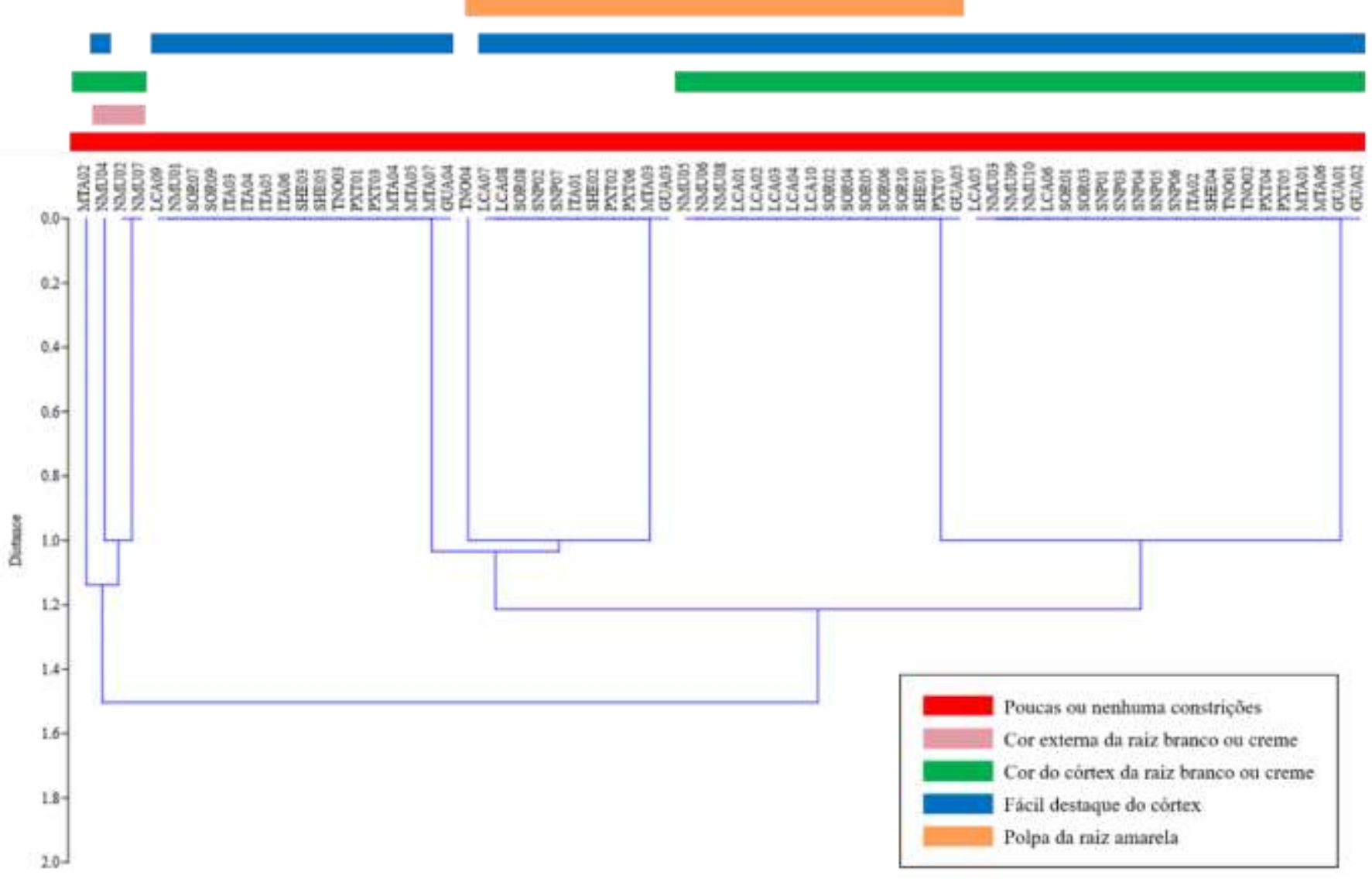

Fonte: Autores.

As mandiocas Paraná (NMU02), Liberata (NMU04) e Mandioca sopa (NMU07), ambas coletadas no munícipio de Nova Mutum, são as únicas, dentre as avaliadas, que apresentam raízes com coloração externa branco ou creme, fator que contribuiu para a separação das três etnovariedades no dendrograma. Conforme Vieira et al. (2008) as mandiocas selecionadas para agroindústrias apresentam raízes com córtex branco ou creme, pois durante o processamento, a retirada da entrecasca (córtex) é, geralmente, manual e alguns resíduos permanecem, podendo comprometer a qualidade do produto final (Brixner, 2015).

Dezesseis etnovariedades, (NMU05, NMU06, NMU08, LCA01, LCA02, LCA03, LCA04, LCA10, SOR02, SOR04, SOR05, SOR06, SOR10, SHE01, PXT07 e GUA05), apresentam quatro das cinco características avaliadas. Dentre elas, encontra-se a cor da polpa amarela que, na região norte de Mato Grosso, é a preferida entre agricultores e consumidores (Tiago et al., 2020). Além disso, a coloração amarela está relacionada aos teores de carotenoides, com destaque para o $\beta$-caroteno, que 
por ser precursor da vitamina A, representa um incremento nutricional. Os programas de melhoramento genético de mandioca de mesa estão focados na seleção de variedades com essa característica, visando à melhoria nutricional das raízes de reserva (Silva et al., 2014).

Esses resultados indicam que as etnovariedades de mandioca cultivadas, por agricultores familiares, no estado de Mato Grosso apresentam potencial para recomendação para cultivo comercial, uma vez que congregam características desejáveis pelos consumidores, podendo ser úteis como progenitoras em programas de melhoramento com a espécie.

\subsection{Caracterização quantitativa}

Com base nos dados quantitativos, houve a formação de oito grupos distintos entre as mandiocas avaliadas, conforme a Figura 7. O grupo I constitui-se por quatro etnovariedades de diferentes locais. Esse grupo apresentou a maior média de diâmetro de raízes tuberosas $(14,41 \mathrm{~cm})$ e ainda alocou as etnovariedades de menor distância genética $(0,144)$, ambas denominadas de Mandioca pão (SNP03 e SOR01), coletadas nos municípios de Sinop e Sorriso, respectivamente. Esse resultado sugere que está havendo uma interação entre os agricultores, ou seja, uma troca de material vegetal (manivas), que muitas vezes ultrapassam municípios e até mesmo regiões. E, conforme Oler e Amorozo (2017) e Figueredo el al. (2019), é importante que esse fluxo de manivas exista e se mantenha, o que garante a ampliação do acervo por novas introduções e, consequentemente, variabilidade genética a espécie. Alves-Pereira et al. (2017) destacam ainda que a inclusão de manivas seguida da propagação clonal é importante para a manutenção e ampliação da diversidade genética em variedades cultivadas.

A maior distância genética (1,573) foi detectada entre as etnovariedades Branca (SOR06) e Mandioca sopa (NMU07), pertencentes ao município de Sorriso e Nova Mutum, respectivamente. A característica altura da planta foi a que contribuiu para o distanciamento da NMU07, apresentando menor média de altura $(0,90 \mathrm{~cm})$.

Figura 6. Dendrograma obtido pelo método de agrupamento UPGMA de 71 etnovariedades de mandioca com base em oito descritores morfoagronômicos quantitativos. $\mathrm{CCC}=0,72$; Ponto de corte $=70,49 \%$.

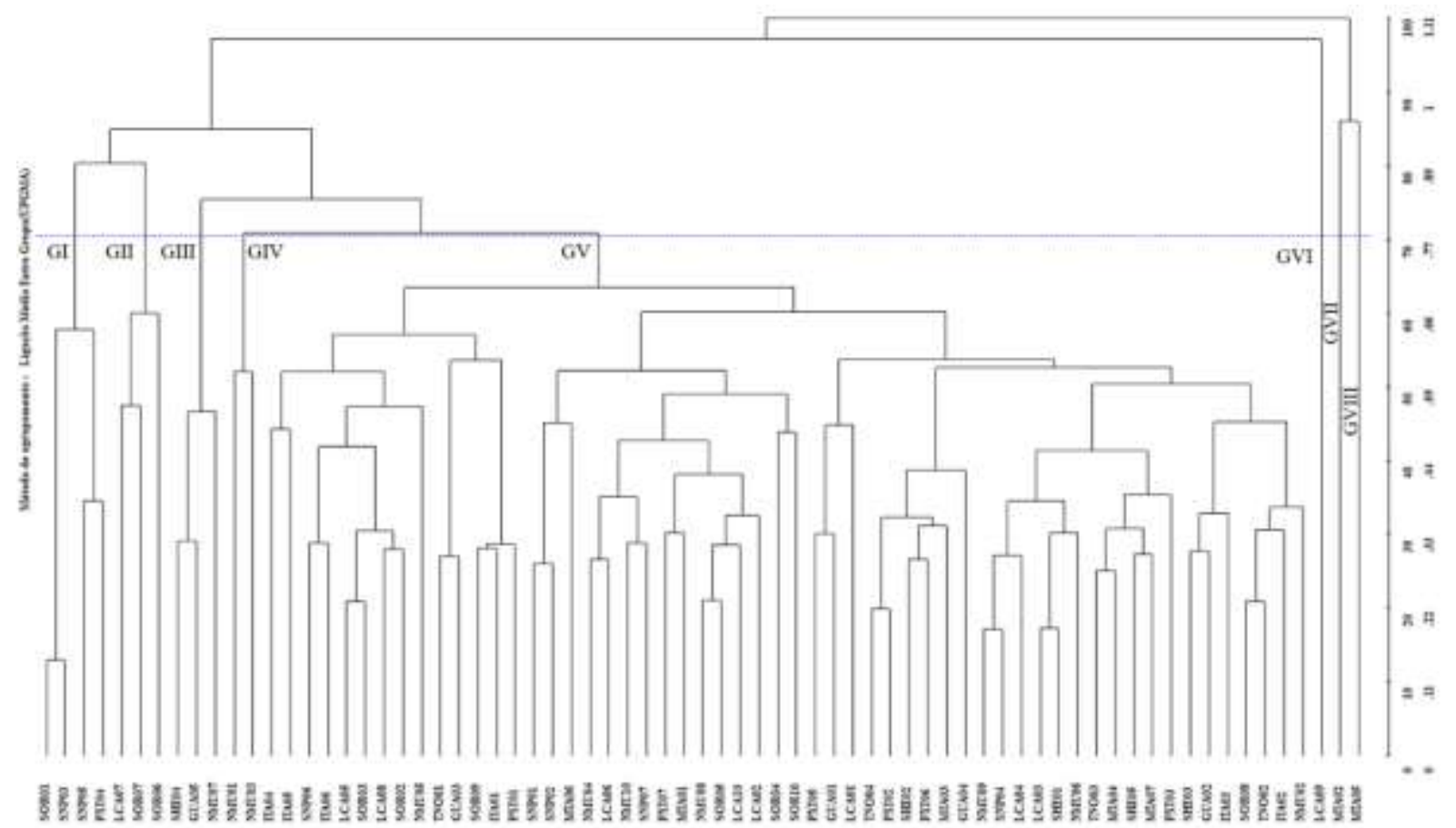

Fonte: Autores. 
Os grupos II e III reuniram três etnovariedades cada. O GII foi composto pelas etnovariedades (LCA07, SOR07 e SOR06) que apresentaram maior média de altura de planta $(2,19 \mathrm{~cm})$ e maior número médio de raízes por planta (12) e o GIII agrupou as etnovariedades (SHE04, GUA05 e NMU07) que apresentaram menores comprimento e largura de lóbulo central e menores comprimento de pecíolo. O grupo IV reuniu duas etnovariedades coletadas no município de Nova Mutum (NMU01 e NMU03), que se destacaram por apresentar maior média de comprimento do lóbulo central $(10,31 \mathrm{~cm})$, maior comprimento médio de pecíolo $(15,93 \mathrm{~cm})$ e maior comprimento médio de raízes $(30,92 \mathrm{~cm})$. O grupo $\mathrm{V}$ foi o mais numeroso e compreendeu cerca de 79\% das etnovariedades avaliadas. Os grupos VI, VII e VIII alocaram uma etnovariedade cada (LCA09, MTA02 e MTA05, respectivamente) destacando-se como as mais divergentes entre o germoplasma avaliado de acordo com as características morfoagronômicas quantitativas.

A etnovariedade Talo roxo (LCA09), coletada no munícipio de Lucas do Rio Verde, se destacou por apresentar folhas com maior largura média de lóbulo central, obtendo média de 8,82 cm (Figura 8A; B). O lóbulo foliar da mandioca contribui para o processo fotossintético, uma vez que folhas mais largas e com maior número de lóbulos aumentam a superfície de absorção da luz, resultando em maior acúmulo de fotoassimilados e reservas pela planta (Silva et al., 2017), destacando, portanto, a importância deste descritor na caracterização da espécie.

A etnovariedade Mandioca branca (MTA02) se destacou por apresentar plantas com maior altura da primeira ramificação $(1,17 \mathrm{~cm}$ ) (Figura $8 \mathrm{C}$ ). E, conforme Gomes et al. (2016), plantas com essa característica facilitam as práticas de manutenção do cultivo (capinas manuais). E a etnovariedade Cacau (MTA05) se isolou no dendrograma por apresentar raízes com menores comprimento e diâmetro (11,15 e 6,20 cm, respectivamente) (Figura 8D).

Figura 7. Características morfoagronômicas quantitativas que mais contribuíram para a diferenciação das etnovariedades Talo roxo (LCA09), Mandioca branca (MTA02) e Cacau (MTA05). A) Folha desenvolvida com maior lóbulo central; B) plantas com maior altura da primeira ramificação; C e D) raízes com menores comprimento e diâmetro.

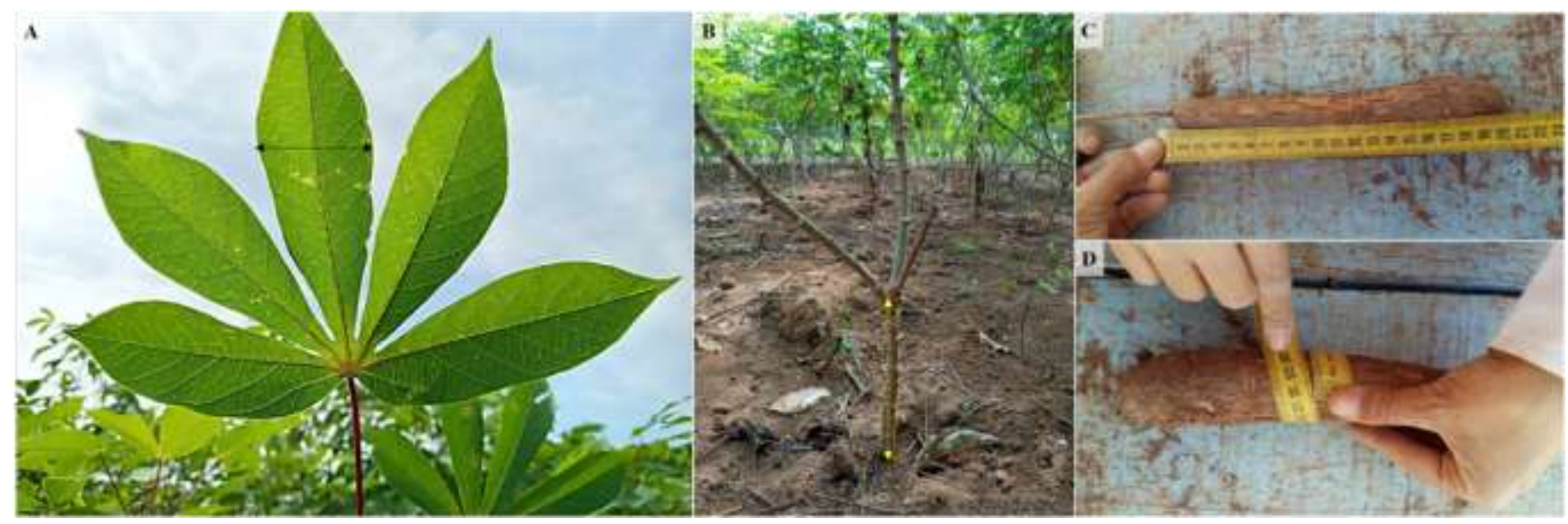

Fonte: Autores.

As características quantitativas que contribuíram para a explicação da diversidade genética entre as 71 etnovariedades de mandioca são mostradas na Tabela 3. O comprimento médio da raiz e o comprimento do pecíolo apresentaram 65,70\% e $14,44 \%$ de contribuição, respectivamente, sendo responsáveis por $80,14 \%$ da diversidade. A variável que menos contribuiu para a diversidade foi a altura da primeira ramificação, que apresentou $0,08 \%$. 
Tabela 3. Contribuição relativa de oito descritores morfoagronômicos quantitativos da mandioca, para a diversidade genética estimada pela metodologia proposta por Singh (1981).

\begin{tabular}{lc}
\hline Descritores & Valor $(\boldsymbol{\%})$ \\
\hline Comprimento médio da raiz & 65,70 \\
Comprimento do pecíolo & 14,44 \\
Número de raízes por planta & 7,57 \\
Diâmetro médio da raiz & 6,40 \\
Comprimento do lóbulo central & 3,65 \\
Largura do lóbulo central & 1,99 \\
Altura da Planta & 0,18 \\
Altura da primeira ramificação & 0,08 \\
\hline
\end{tabular}

Fonte: Autores.

Tiago et al. (2020), avaliando 45 etnovariedades de mandioca no estado de Mato Grosso, também detectaram que as características que mais contribuíram para distinção das mandiocas foram o comprimento da raiz (30,23\%) e o comprimento do pecíolo (20,82\%). Giles et al. (2018), também encontraram o comprimento do pecíolo entre os descritores que mais contribuíram $(22,86 \%)$ para a diversidade entre os 12 genótipos de M. esculenta estudados no estado do Espírito Santo. Resultados semelhantes também foram encontrados por Zuin et al. (2009), avaliando acessos de mandioca cultivados na região urbana do município de Cianorte-PR, sendo o comprimento médio das raízes o descritor que mais contribuiu (32,04\%) para a diversidade entre os acessos.

\subsection{Análise conjunta}

A distância genética, estimada por meio da análise conjunta dos caracteres qualitativos e quantitativos, evidenciou que as etnovariedades geneticamente mais próximas (4,266) foram PXT06 (Mandioca Preta) e MTA03 (Amarelinha), coletadas em diferentes municípios; a maior distância genética $(15,900)$ foi observada entre as etnovariedades NMU07 e LCA07, denominadas pelos agricultores por Mandioca sopa e Folha roxa, provenientes dos municípios de Nova Mutum e Lucas do Rio Verde, respectivamente.

O dendrograma obtido pelo método de agrupamento UPGMA permitiu a formação de nove grupos distintos entre as etnovariedades (Figura 9). A análise conjunta de caracteres qualitativos e quantitativos tem sido apontada como ferramenta útil na estimativa da diversidade genética, uma vez que, por meio desses estudos, é possível traçar estratégias para orientar ações de conservação e uso dos recursos genéticos disponíveis (Vieira et al., 2013).

O grupo I e II foram os mais numerosos, compreendendo 35 e 19 etnovariedades, respectivamente, de diferentes municípios de coleta e apresentando variabilidade para os descritores avaliados. O grupo III, IV, V e IX isolaram as etnovariedades Vassourinha (MTA01), Casca roxa (GUA04), Folha roxa (LCA07) e Mandioca branca (MTA02), respectivamente, sendo, portanto, as mais dissimilares entre o material avaliado. O grupo VI reuniu sete etnovariedades e os grupos GVII e GVIII alocaram três etnovariedades cada, de diferentes locais de coleta. A etnovariedade Mandioca branca (MTA02), coletada no município de Matupá, permaneceu isolada nesta análise, confirmando a variabilidade detectada nas análises individuais das características qualitativas e quantitativas. 
Figura 8. Dendrograma de dissimilaridade genética entre 71 etnovariedades de mandioca, obtido pelo método de agrupamento UPGMA, com base no algoritmo de Gower, a partir de 31 descritores qualitativos e oito quantitativos. CCC = 0,68; Ponto de corte $=78,56 \%$.

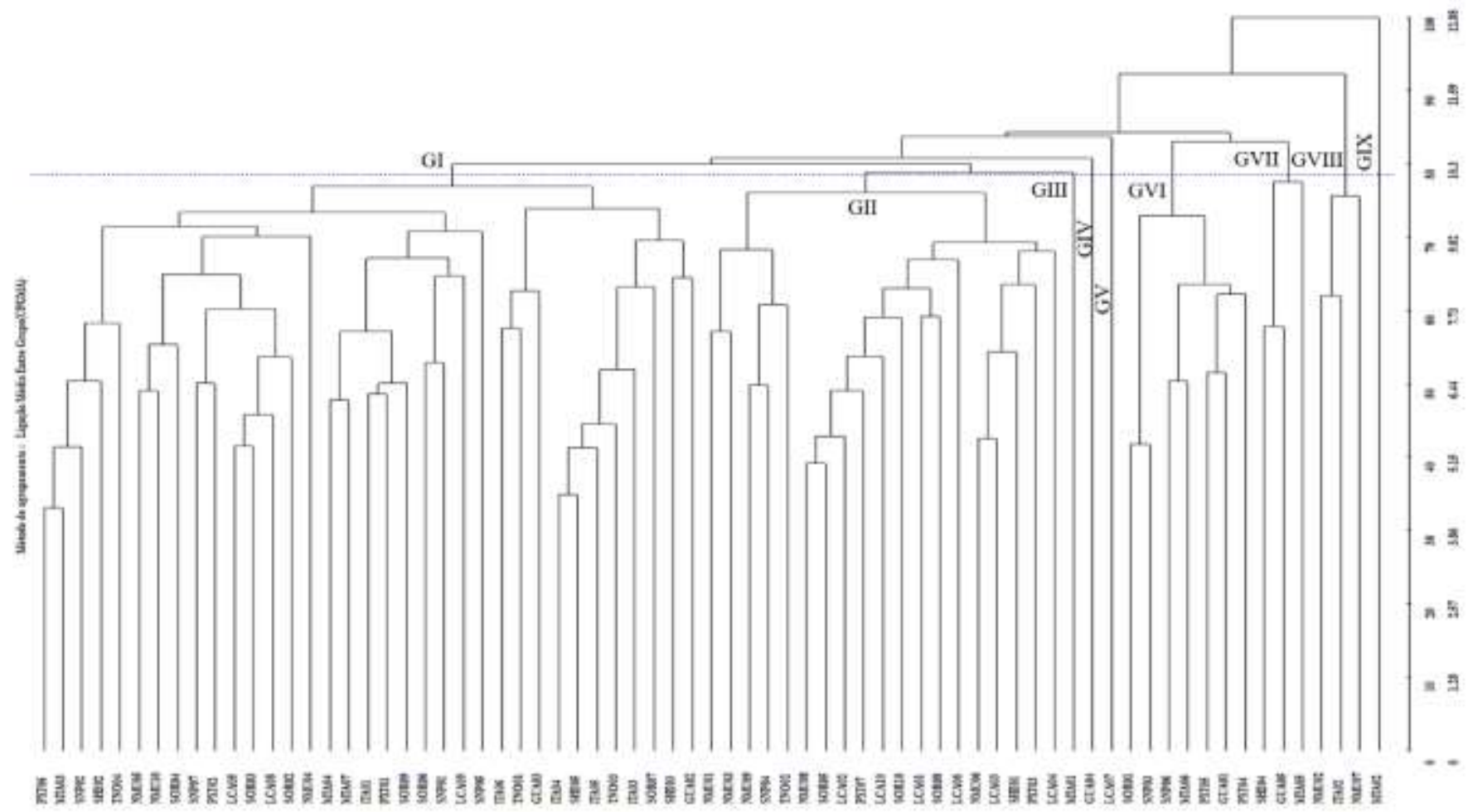

Fonte: Autores.

Nas três análises de agrupamento (qualitativa, quantitativa e conjunta), houve a formação de grupos e subgrupos, confirmando a diversidade genética existente entre as etnovariedades de mandioca cultivadas e conservadas nas roças dos agricultores familiares na região norte de Mato Grosso. Conforme Léotard et al. (2009) a domesticação da espécie M. esculenta ocorreu na Amazônia, o que explica, em parte, a variabilidade identificada nessa região. Esta semelhança na discriminação de genótipos pela diversidade genética também é relatada por Zuin et al. (2009), Vendramini et al. (2011) e Giles et al. (2018) com a espécie M. esculenta.

Diante da diversidade detectada entre as etnovariedades, destaca-se o papel dos agricultores na conservação desses recursos genéticos, sendo a troca de material vegetal (manivas) um dos fatores que contribuem para o aumento da variabilidade dos acervos. Portanto, os agricultores devem ser vistos como colaboradores na conservação on farm dos recursos genéticos da mandioca, pois mantém e ampliam a variabilidade genética em suas roças, e, conforme Figueredo et al. (2019), a conservação on farm tem sido vista pelos pesquisadores, melhoristas e curadores de banco de germoplasma de mandioca como uma opção viável e possível de ser realizada, tanto pelo baixo custo, como por permitir a dinâmica evolucionária da espécie.

\section{Conclusão}

As etnovariedades de mandioca cultivadas no norte do estado de Mato Grosso apresentam variabilidade fenotípica quanto aos descritores morfoagronômicos avaliados.

A etnovariedade Mandioca branca (MTA02) foi a mais divergente do conjunto avaliado, com base nas análises qualitativa, quantitativa e conjunta. 
Dentre as 71 etnovariedades de mandioca avaliadas, a maioria apresenta potencial para cultivos comerciais, uma vez que congregam características desejáveis pelos consumidores no momento da compra, podendo ser úteis como progenitoras em programas de melhoramento com a espécie.

Para o uso em processamento agroindustrial, as etnovariedades Paraná (NMU02), Liberata (NMU04) e Mandioca sopa (NMUU07), são recomendadas por apresentar raízes com coloração externa branca ou creme.

As etnovariedades que se destacaram, tanto para cultivo comercial como para processamento agroindustrial, seguirão para estudos posteriores, sendo avaliadas quanto ao desempenho produtivo e qualidade culinária em diferentes locais do estado de Mato Grosso. Dessa forma, indicaremos etnovariedades quanto aos caracteres fenotípicos de importância para os agricultores, considerando a interação genótipo x ambiente.

\section{Agradecimentos}

O presente trabalho foi realizado com apoio da Coordenação de Aperfeiçoamento de Pessoal de Nível Superior Brasil (CAPES) - Código de Financiamento 001.

\section{Referências}

Adjebeng-Danquah, J., Gracen, V. E., Offei, S. K., Asante, I. K. \& Manu-Aduening, J. (2016). Agronomic performance and genotypic diversity for morphological traits among cassava genotypes in the Guinea Savannah Ecology of Ghana. Journal of Crop Science and Biotechnology, 19(1):99-108.

Alvares, C. A., Stape, J. L., Sentelhas, P. C., Gonçalves, J. L. M. \& Sparovek, G. (2013). Koppen's climate classification map for Brazil. Meteorologische Zeitschrift, 22(6):711-728.

Alves, A. A. C. \& Setter, T. L. (2000). Response of Cassava to Water Deficit: Leaf Area Growth and Abscisic Acid. Crop Science, $40(1): 131-137$.

Alves-Pereira, A., Peroni, N., Cavallari, M. M., Lemes, M. R., Zucchi, M. I. \& Clement, C. R. (2017). High genetic diversity among and within bitter manioc varieties cultivated in different soil types in Central Amazonia. Genetics and Molecular Biology, 40(2):468- 479.

Aplevicz, K. S. \& Demiate, I. M. (2007). Caracterização de amidos de mandioca nativos e modificados e utilização em produtos panificados. Ciência $e$ Tecnologia de Alimentos, 27(3):478-484.

BFG. (2015). Growing knowledge: an overview of Seed Plant diversity in Brazil. Rodriguésia, 66(4):1085-1113.

Brown, C. H., Clement, C. R., Epps, P., Luedeling, E. \& Wichmann, S. (2013). The Paleobiolinguistics of Domesticated Manioc (Manihot esculenta). Ethnobiology Letters, 4:61-70.

Cole-Rodger, P., Smith, D. W. \& Bosland, P. W. (1997). A novel statistical approach to analyze genetic resources evalutions using Capsicum as na example. Crop Science, 37:1000-1002.

Cordeiro, I. Secco, R., Silva, M. J., Sodré, R. C. \& Martins, M. L. L. (2015). Manihot in Lista de Espécies da Flora do Brasil. Jardim Botânico do Rio de Janeiro. http://floradobrasil.jbrj.gov.br/jabot/floradobrasil/FB17591

Cruz, C. D. (2016). Genes Software - extended and integrated with the R, Matlab and Selegen. Acta Scientiarum, 38(4):547-552.

Cruz, C. D., Medeiros, F. F. \& Pessoni, L. A. (2011). Biometria aplicada ao estudo da diversidade genética. UFV. 620p.

Ebertz, O. F. \& Palomino, E. C. (2017). Caracterização morfológica de genótipos de Manihot esculenta Crantz obtidos via sementes. Agroecossistemas, 9(2):66-77.

EMBRAPA. Empresa Brasileira De Pesquisa Agropecuária. (2013). Sistema Brasileiro de Classificação de Solos. (3a ed.), Embrapa Solos.

Figueredo, P. E. Tiago, A. V., Zanetti, G. T., Pinto, J. M. A., Rossi, A. A. B. \& Hoogerheide, E. S. S. (2019). Diversidade genética de mandiocas na região periurbana de Sinop, Mato Grosso, Brasil. Magistra, 30:143-153.

Fuhrmann, E., Vieira, E. A., Faleiro, F. G., Fialho, J. F. \& Carvalho, L. J. C. B. (2016). Caracterização morfológica de clones elite de mandioca de mesa amarelos biofortificados. Magistra, 28(3/4):427-438.

Fukuda, W. M. G. \& Guevara, C. L. (1998). Descritores morfológicos e agronômicos para a caracterização de mandioca (Manihot esculenta Crantz). Cruz das Almas: CNPMF, 38p.

Giles, J. A. D., Oliosi, G., Rodrigues, W. P., Braun, H., Ribeiro-Barros, A. I. \& Partelli, F. L. (2018). Agronomic performance and genetic divergence between genotypes of Manihot esculenta. Anais da Academia Brasileira de Ciências, 90(4):3639-3648. 
Research, Society and Development, v. 10, n. 5, e25410514871, 2021

(CC BY 4.0) | ISSN 2525-3409 | DOI: http://dx.doi.org/10.33448/rsd-v10i5.14871

Gomes, R. S., Almeida, C. F., Costa, J. R. S., Machado Junior, R., Delazari, F. T., Santos, F. C. S. \& Silva, D. J. H. (2016). Genetic diversity in sweet cassava from the Brazilian Middle North Region and selection of genotypes based on morpho-agronomical descriptors. African Journal of Agricultural Research, 11(38):3710-3719.

Gower, J. C. (1971). A general coefficient of similarity and some of its properties. Biometrics, 27(4):857-871.

Hammer, Ø., Harper, D. А. T. \& Ryan, P. D. (2001). Past: Paleontological statistics software package for education and data analysis. Palaeontologia Electronica, 4(1):1-9.

IBGE. Instituto Brasileiro de Geografia e Estatística. Cidades e Estados (2019). https://www.ibge.gov.br/cidades-e-estados/mt/alta-floresta.html.

Léotard, G., Duputié, A., Kjellberg, F., Douzery, E. J. P., Debain, C., Granville, J-J. \& Mckey, D. (2009). Phylogeography and the origin of cassava: New insights from the northernrim of the Amazonian basin. Molecular Phylogenetics and Evolution, 53:329-334, 2009.

Menezes, J. B. C., Catão, H. C. R. M., Costa, C. A. \& Chauca, M. N. C. (2019). Aspectos agronômicos e qualidade de raízes de mandioca minimamente processadas. Revista Agrarian, 12(46):425-433.

Mojena, R. (1977). Hierarchical grouping methods and stopping rules: an evaluation. The Computer Journal, 20:359-363.

Oler, J. R. L. \& Amorozo, M. C. M. (2017). Etnobotânica e conservação on farm de mandioca (Manihot esculenta Crantz) na agricultura de pequena escala no Estado de Mato Grosso, Brasil. Interações, 18(4):137-153.

Pedri, E. C. M., Hoogerheide, E. S. S., Tiago, A. V., Cardoso, E. S., Pinto, J. M. A., Santos, L. L. Yamashita, O. M. \& Rossi, A. A. B. (2019). Genetic diversity of cassava landraces cultivated in northern Mato Grosso State, Brazil, using microsatellite markers. Genetics and Molecular Research, 18(3): gmr18315.

Silva, D. C. O., Alves, J. M. A., Uchôa, S. C. P., Sousa, A. A., Barreto, G. F. \& Silva, C. N. (2017). Curvas de crescimento de plantas de mandioca submetidas a doses de potássio. Revista de Ciências Agrárias, 60(2):158-165.

Silva, K. N., Vieira, E. A., Fialho, J. F., Carvalho, L. J. C. B. \& Silva, M. S. (2014). Potencial agronômico e teor de carotenoides em raízes de reserva de mandioca. Ciência Rural, 44(8):1348-1354.

Singh, D. (1981). The relative importance of characters affecting genetic divergence. Indian Journal of Genetics and Plant Breeding, 4:237-245.

Teixeira, P. R. G., Viana, A. E. S., Cardoso, A. D., Lopes, S. C., Guimarães, D. G. \& Bastos, A. C. (2014). Características morfológicas de quatro variedades de mandioca de mesa cultivadas em Vitória da Conquista - BA. Revista Raízes e Amidos Tropicais, 10(1):1-8.

Tiago, A. V., Hoogerheide, E. S. S., Pedri, E. C. M., Rossi, F. R., Cardoso, E. S., Pinto, J. M. A., Pena, G. F. \& Rossi, A. A. B. (2019). Genetic diversity and population structure of cassava ethno-varieties grown in six municipalities in the state of Mato Grosso, Brazil. Genetics and Molecular Research, 18(4): gmr18357.

Tiago, A. V., Pedri, E. C. M., Rossi, F. S., Santos, L. L., Lima, J. A., Cardoso, E. S., Roveda, A. P., Hoogerheide, E. S. S. \& Rossi, A. A. B. (2020). Phenotypic characterization of cassava ethno-varieties in the state of Mato Grosso, Brazil. Genetics and Molecular Research, 19(2): gmr18538.

Vargas, P. F., Engelking, E. W., Almeida, L. C. F., Ferreira, A. \& Charlo, H. C. O. (2018). Genetic diversity among sweet potato crops cultivated by traditional farmers. Revista Caatinga, 31(3):779-790.

Vendramini, J. M., Neves, L. G., Barelli, M. A. A., Elias, J. C. F. \& Luz, P. B. (2011). Otimização do uso dos descritores morfo-agronômicos de mandioca em análise multivariada. Revista Ciência Agronômica, 42(4):906-913, 2011.

Vieira, E. A., Fialho, J. F., Faleiro, F. G., Bellon, G., Fonseca, K. G., Silva, M. S., Paula-Moraes, S. V. \& Carvalho, L. J. C. B. (2013). Caracterização fenotípica e molecular de acessos de mandioca de indústria com potencial de adaptação às condições do Cerrado do Brasil Central. Semina: Ciências Agrárias, 34(2):567-582.

Vieira, E. A., Fialho, J. F., Silva, M. S., Fukuda, W. M. G. \& Faleiro, F. G. (2008). Variabilidade genética do banco de germoplasma de mandioca da Embrapa cerrados acessada por meio de descritores morfológicos. Científica, 36(1):56 - 67.

Zago, B. W., Barelli, M. A. A., Hoogerheide, E. S. S., Corrêa, C. L., Delforno, G. I. S., \& Da Silva, C. J. (2017). Morphological diversity of cassava accessions of the south-central mesoregion of the State of Mato Grosso, Brazil. Genetics and Molecular Research, 16(3), gmr16039725.

Zuin, G. C., Vidigal Filho, P. S., Kvitschal, M. V., Gonçalves-Vidigal, M. C. \& Coimbra, G. K. (2009). Divergência genética entre acessos de mandioca-demesa coletados no município de Cianorte, região Noroeste do Estado do Paraná. Semina: Ciências Agrárias, 30(1):21-30. 